\title{
E्द्धreatidara
}

\section{Ações de Formação em EJA nas Prisões: o que pensam os professores do sistema prisional do Ceará?}

Wagner Bandeira Andriola

RESUMO - Ações de Formação em EJA nas Prisões: o que pensam os professores do sistema prisional do Ceará? ${ }^{1} \mathrm{O}$ texto relata as principais ações de Educação de Jovens e Adultos (EJA) que são desenvolvidas com profissionais do Sistema Prisional do Ceará. Atualmente, no Brasil são desenvolvidas tão somente duas ações de formação de professores do Sistema Prisional, no nível de especialização, uma delas executada no Ceará. Cabe destacar outras ações desenvolvidas no Ceará: formação de 220 agentes prisionais; análise de dados secundários da PNAD/2007 - Suplemento de EJA; financiamento de projetos de pesquisa pelo CNPq; formação de novos pesquisadores no nível de mestrado; articulação da Universidade Federal do Ceará (UFC) com o Ministério da Educação, com a Escola de Gestão Penitenciária e Ressocialização e com a Secretaria de Justiça e Cidadania.

Palavras-chave: Educação de Jovens e Adultos (EJA). Educação Prisional. Formação de Professores.

ABSTRACT - Educational Activities of Adults and Youth in Prisons: what teachers think of the prison system of the state of Ceará? This paper reports the main educational activities of young people and adults which have been developed aimed at professionals in the prisons of Ceará state. Currently in Brazil are developed merely two actions of teacher Prison System, the level of expertise, one of which is running in Ceará state. In addition to this action, fit note, in Ceará, actions for the training of 220 prison officers, the secondary data analysis of PNAD/2007 - Supplement EJA; funding of research projects by CNPq, the training of new researchers in the master's level; the formation of new researchers in the master's level, the articulation of the UFC with the Ministry of Education, with Penitentiary School of Management and Resocialization and the Department of Justice and Citizenship.

Keywords: Youth and Adults Education. Prison Education. Teacher Training.

Educação \& Realidade, Porto Alegre, v. 38, n. 1, p. 179-204, jan./mar. 2013.

Disponível em: <http://www.ufrgs.br/edu_realidade> 


\section{Antecedentes Históricos}

No âmbito federal, sabe-se que o Sistema Prisional brasileiro convive, desde há muito, com graves deficiências de ordem estrutural, tais como: número insuficiente e superlotação de Unidades Prisionais; precariedade e comprometimento da dimensão física das Unidades Prisionais; desrespeito de alguns direitos básicos dos reclusos (acesso à Educação, por exemplo); desqualificação de parcela substancial dos profissionais que atuam nas Unidades Prisionais; diminuto reconhecimento social e baixos salários desses profissionais; dentre outros graves problemas (Julião, 2006; Santiago; Britto, 2006).

Vale ressaltar, ainda, que, ademais das deficiências decorrentes do modelo carcerário em vigência, o Estado brasileiro, até muito recentemente, não priorizava ações educacionais orientadas ao Sistema Prisional (Julião, 2007). Assim parecem indicar dados presentes em estatísticas oficiais, bem como alguns fatos relatados nos noticiários da mídia em geral, que têm sido muito bem explorados pela imprensa sensacionalista (Onofre, 2007). Some-se a tudo isso uma sociedade que, embora vivencie há pouco mais de duas décadas uma atmosfera democrática, vislumbra de modo mais claro, dia após dia, os seus direitos e os seus deveres; anseia e cobra dos gestores públicos e dos governantes melhorias substanciais em várias frentes, sendo uma delas o Sistema Prisional (Graciano; Schilling, 2008). Foi nesse âmbito que se inseriu a ação conjunta, iniciada em 2005, entre o Ministério da Educação (MEC) e o Ministério da Justiça (MJ), que visou implementar ações educacionais direcionadas ao Sistema Prisional, sob o rótulo de Projeto Educando para a Liberdade, e que se enquadrou nos programas gerenciados pela Secretaria de Educação Continuada, Alfabetização e Diversidade (SECAD/MEC), conforme atestou Teixeira (2007).

\section{EJA nas Prisões: o Projeto Educando para a Liberdade}

O Projeto Educando para a Liberdade traduziu, em primeiro lugar, o imperioso princípio democrático de incluir os excluídos sociais. Em segundo lugar, mas não menos importante, traduziu a preocupação em garantir a qualidade da oferta de Educação voltada ao Sistema Prisional, preconizando um modelo orientado a promover, estimular e reconhecer os avanços e progressos dos educandos reclusos, contribuindo, desse modo, para a restauração da autoestima com vistas à reintegração harmônica à vida em sociedade (UNESCO, 2009).

Os desafios encontrados pelo MEC e pelo MJ para o enfrentamento dessa situação desdobravam-se, em síntese, em dois níveis: a extensão dos serviços regulares, incluindo-se a população prisional nas políticas oficiais do Estado brasileiro para a Educação de Jovens e Adultos (EJA), a modalidade adequada para o público em questão; e a definição de parâmetros que ajudassem a pautar oferta de mais qualidade, em 
consonância com as necessidades e aspirações do público a ser atendido. A educação a ser oferecida, além de seus aspectos formais de conteúdos adequados de formação e maturidade dos educandos, deveria ainda contribuir para o desenvolvimento desta capacidade de recuperação psicológica e social, para permitir tornar-se sujeito da própria história, além de estar associada à oferta de opções de profissionalização e de geração de renda (Julião, 2006; 2007).

Nesse sentido, foram definidas três principais dimensões do Projeto Educando para a Liberdade, a saber: a primeira dimensão relacionava-se à mobilização e à articulação das pastas das Secretarias da Educação e da Administração Penitenciária nos Estados para uma oferta educacional coordenada. Sem que essa relação estivesse estabelecida em bases sólidas, a tendência era de que uma Secretaria sempre buscasse colocar sobre os ombros do outro a responsabilidade pelo nãoatendimento. Por isso, era necessário fortalecer um canal de interlocução entre essas instituições e seus principais dirigentes, para o qual as atuações do governo federal e da própria Organização das Nações Unidas para a Educação, a Ciência e a Cultura (UNESCO) constituíram-se estratégicas.

A segunda dimensão abrangia as identidades e as práticas dos profissionais que ajudam a organizar o atendimento educacional no interior dos estabelecimentos prisionais. Por um lado, realçava-se a necessidade de formação diferenciada dos professores, para que soubessem lidar com as características do público e do ambiente em que trabalham. Por outro lado, denunciava-se como o desencontro entre segurança e assistência prejudicava os direitos da população prisional. Além disso, ainda destacava-se a necessidade de valorização dos mais diversos segmentos da execução penal, diluindo-se a imagem precária com que aparecem ante a sociedade e os próprios presos.

A terceira dimensão, por fim, compreendia os aspectos de ordem pedagógica. Embora motivada por uma realidade bastante particular (as prisões), ela se mostrava tributária de outras discussões igualmente bem assentadas no campo da educação de jovens e adultos e da educação popular. Como assegurar que a educação nas prisões possa ajudar a promover a autonomia e a emancipação dos sujeitos envolvidos?

Observa-se, portanto, a premente necessidade de ações que permitam o aprimoramento da formação dos Gestores das Unidades Prisionais, dos Agentes Prisionais e dos Professores, de modo que estes sejam sensibilizados e, assim, saibam lidar de modo adequado e pertinente, com as características do público e do ambiente em que trabalham (UNESCO, 2009). Outro pressuposto presente na referida proposta, este talvez o mais importante, era a vontade de incluir aqueles que se encontram, na atualidade, excluídos de oportunidades educacionais.

O Estado do Ceará participou do desenvolvimento deste projeto desde a sua fase de elaboração, sediando um dos seminários regionais 
e executando inúmeras atividades em sua primeira etapa. Antes da implantação do Projeto Educando para a Liberdade, as ações direcionadas às formações dos recursos humanos do Sistema Prisional eram desenvolvidas timidamente, a partir de alguns cursos que não integravam os vários segmentos de profissionais do referido sistema, atendendo pontualmente as demandas de um destes segmentos referidos há pouco, sem haver a unificação de ações de formação (Teles; Duarte, 2009).

A inovação trazida pelo Projeto Educando para a Liberdade permitiu a execução, em 2006, de um Curso de Formação continuada destinado aos professores e servidores do Sistema Prisional, que envolveu 540 profissionais, entre Agentes e Gestores $(\mathrm{n}=482)$, bem como Educadores $(\mathrm{n}=58)$. Esta atividade mostrou a necessidade de os responsáveis pelo Sistema Prisional atentarem para o quanto é relevante a preparação dos trabalhadores do referido sistema, dada a relação direta com os sujeitos privados de liberdade e com os seus educadores. A oportunidade de interagir com outros trabalhadores do Sistema Prisional deixaram, nos Educadores, o desejo de aprofundar reflexões, de buscar soluções para carências profissionais e de elaborar uma proposta pedagógica específica para o Sistema Educacional.

\section{Avaliação do $2^{\circ}$ Ciclo do Projeto Educando para a Liberdade}

Uma das experiências de relevo da Universidade Federal do Ceará (UFC) na área de EJA nas prisões foi proporcionada pela execução da avaliação do $2^{\circ}$ Ciclo do Projeto Educando para a Liberdade. Tal atividade foi demandada pela Secretaria de Educação Continuada, Alfabetização e Diversidade (SECAD). A referida ação foi executada no biênio 2007/2008 por um grupo de especialistas da Universidade Federal do Ceará (UFC), com o objetivo geral de realizar diagnóstico das repercussões individuais para os alunos reclusos das escolas partícipes do $2^{\circ} \mathrm{Ci}-$ clo do Projeto Educando para a Liberdade que estava sendo desenvolvido nos estados do Acre, Espírito Santo, Maranhão, Mato Grosso do Sul, Pará e Pernambuco. Buscou-se, ainda, diagnóstico e sugestões válidas para o aprimoramento do Projeto Educando para a Liberdade.

Essa singular atividade permitiu a este grupo a aquisição de know-how diferenciado, no âmbito da avaliação de programas e de projetos sociais, diretamente vinculados à Educação Prisional, ademais de ter proporcionado à consolidação de uma equipe de pesquisadores com expertise na referida temática. Como resultado, houve a publicação de dois capítulos de livros editados pela UNESCO com a descrição dos principais resultados da avaliação do $2^{\circ}$ Ciclo do Projeto Educando para a Liberdade (Andriola et al. 2008, 2009).

Porém, as atividades decorrentes dessa primeira experiência da equipe da UFC na área de EJA nas prisões originaram dois outros conjuntos de ações: de pesquisa e de formação, que são referidas a seguir. 


\section{Ações de Pesquisa em EJA nas Prisões}

\section{Pesquisa com Dados Primários}

Em 2007, os pesquisadores do projeto apresentaram no I Encontro de Pesquisa da UFC o trabalho intitulado Mapeamento do Perfil do Educador do Sistema Prisional e as Condições Pedagógicas de Atuação. Em maio de 2008 o Grupo de Pesquisa da UFC, coordenado pelo Prof. Wagner Bandeira Andriola, foi contemplado com duas bolsas de Iniciação Científica (IC) da Fundação Cearense de Apoio ao Desenvolvimento Científico e Tecnológico (FUNCAP), que foram utilizadas por dois alunos de Graduação em Pedagogia. Nessa ocasião, esses alunos apresentaram trabalhos decorrentes da avaliação do $2^{\circ}$ Ciclo do Projeto Educando para a Liberdade no XXVII Encontro de Iniciação Científica da UFC, realizado em 2008.

Ainda em 2008, como resultado dessas ações iniciais na área da EJA nas prisões, o coordenador do projeto submeteu ao Conselho Nacional de Desenvolvimento Científico e Tecnológico (CNPq) uma proposta de pesquisa que foi prontamente aprovada. Como resultado, dois bolsistas foram financiados pelo CNPq (um de graduação - Bolsa de Iniciação Científica; outro no nível de pós-graduação - Bolsa de Mestrado). A dissertação do mestrando foi defendida em agosto de 2011, na qual foram apresentados os resultados da avaliação diagnóstica das atividades educacionais oferecidas e executadas pelas Unidades Prisionais no Brasil.

Já no ano de 2009 houve a apresentação de outros resultados oriundos da avaliação do $2^{\circ}$ Ciclo do Projeto Educando para a Liberda$d e$, que foi efetivada durante o XXVIII Encontro de Iniciação Científica da UFC. Nesta ocasião foram três as bolsistas de IC (da FUNCAP e do CNPq).

No que diz respeito à apresentação de resultados em congressos e reuniões científicas de âmbito nacional, há que se destacar a participação de pesquisadores na Reunião anual da Associação Brasileira de Avaliação Educacional (ABAVE), que foi realizada em junho de $2009 \mathrm{em}$ Salvador, na Bahia. Nessa ocasião, houve uma comunicação oral do coordenador do projeto abordando os principais resultados da avaliação do $2^{\circ}$ Ciclo do Projeto Educando para a Liberdade. Outro trabalho foi apresentado no XV Encontro Nacional de Didática e Prática de Ensino (ENDIPE), realizado em Belo Horizonte (MG) em abril de 2010.

Para finalizar esse tópico, convém destacar que em 2010 publicouse um artigo científico na Revista Ibero-americana de Avaliação Educacional (RIEE) ${ }^{2}$ ilustrando o uso do Modelo Contexto, Insumo, Processo e Produto (CIPP) para avaliar o $2^{\circ}$ Ciclo do Projeto Educando para a Liberdade a partir de quatro dimensões analíticas: o Contexto (macro, meso e micro), os Insumos (humanos e materiais), os Processos e os Produtos (Andriola, 2010).

Educação \& Realidade, Porto Alegre, v. 38, n. 1, p. 179-204, jan./mar. 2013. 183

Disponível em: <http://www.ufrgs.br/edu_realidade> 
Ações de Formação em EJA nas Prisões

\section{Pesquisa com Dados Secundários}

Em 2007, o Instituto Brasileiro de Geografia e Estatística (IBGE) divulgou os resultados do levantamento suplementar da Pesquisa Nacional por Amostra de Domicílios (PNAD) versando sobre a educação profissional e aspectos complementares da Educação de Jovens e Adultos (EJA), como resultado de um convênio estabelecido com o Ministério da Educação (MEC). A pesquisa sobre os aspectos complementares da EJA objetivou captar o alcance desta forma de educação, voltada para dar oportunidade de formação à população que não teve acesso ou que não teve possibilidade de completar os níveis de educação fundamental e média, e de alfabetização nas idades apropriadas, caracterizando aspectos relevantes relacionados aos cursos oferecidos nas diferentes modalidades. Já a pesquisa sobre educação profissional visou a traçar um perfil da população relacionado ao acesso e formação nos segmentos de qualificação profissional, técnico de nível médio e graduação tecnológica.

Não obstante, apesar do referido estudo e dada a riqueza de dados e de informações existentes na base do IBGE, obtidos pela PNAD - 2007, bem como pela complexidade da temática e da sua relevância educacional e social, a SECAD propôs-se a aprofundar os estudos, as análises e as reflexões destes dados através de ações analíticas aprofundadas e sistematizadas por grupo de especialistas em EJA. Com esse objetivo uma equipe de especialistas da UFC foi contratada em 2010 pela SECAD/ MEC, com o objetivo de usar os microdados da PNAD - 2007 para gerar relevante conjunto de informações analíticas, de modo a subsidiar análises críticas, planejamentos futuros e decisões voltadas à implementação das Políticas Públicas de EJA no Brasil. O início dos trabalhos de análise deu-se em janeiro de 2010 com relatórios gerais e setoriais (por Unidade Federativa) enviados à SECAD/MEC em janeiro de 2011.

\section{Ações de Formação em EJA nas Prisões}

No que tange às ações de formação de recursos humanos em EJA nas prisões, há que se destacar o curso de aperfeiçoamento destinado aos gestores e aos agentes do sistema prisional do Estado do Ceará, implementado em 2010 e financiado pela SECAD/MEC. O referido curso foi executado pela UFC, em parceria com a Escola de Gestão Penitenciária e Formação para a Ressocialização (EGPR) da Secretaria de Justiça (SEJUS) do Ceará. Tratou-se de uma ação pioneira, que proporcionou a formação de 220 profissionais do sistema prisional.

Dado que o curso de aperfeiçoamento tinha que abordar pelo menos $50 \%$ da sua carga horária para os fundamentos, os princípios e as estratégias metodológicas na EJA, e que os outros $50 \%$ deveriam ser utilizados para os conhecimentos específicos, voltados, nesse caso, à Educação Prisional (população carcerária), a proposta fundamentou-se 
em dois blocos, a saber: bloco de conteúdos básicos e bloco de conteúdos específicos. Os conteúdos básicos referiam-se à Educação de Jovens e Adultos (EJA), enquanto os conteúdos específicos estavam associados à EJA nas prisões, de modo a que os alunos pudessem, efetivamente, reconhecerem-se como sujeitos ativos e fazer uso corriqueiro desses conteúdos no âmbito das prisões, com o intuito de transformarem-se e de transformarem a realidade na qual estão inseridos.

\section{Formação em EJA nas Prisões: é possível haver casamento entre os cursos dirigidos aos agentes, gestores e professores do Sistema Prisional do Ceará?}

Como se pode perceber houve, claramente, uma linha de união entre as ações de pesquisa dos profissionais da UFC envolvidos na avaliação do $2^{\circ}$ Ciclo do Projeto Educando para a Liberdade (SECAD/MEC) com as atividades de formação de recursos humanos em EJA nas prisões. Ademais, houve uma confluência de interesses públicos para impulsionar e consolidar essas ações, decorrentes das iniciativas de distintos agentes financiadores: CNPq, SECAD/MEC e Secretaria de Justiça (SEJUS) do Ceará. Estes agentes de fomento têm contribuído com a geração de novos conhecimentos na área de EJA, através das pesquisas, bem como para a formação de nova mentalidade entre os recursos humanos que lidam diretamente com os sujeitos da EJA nas prisões.

Desse modo, houve uma racionalidade e desejo político que nos conduzirão, inevitavelmente, à transformação de uma parte substancial da sociedade, que tem sido privada de oportunidades educacionais, sobretudo entre segmentos sociais que, embora sem liberdade, enxergam de modo paradoxal oportunidades educacionais. Sendo assim, não há outro caminho a seguir que não seja o de assegurar a execução de ações de pesquisa e de formação de recursos humanos em EJA nas prisões, amparadas na competência técnica e na responsabilidade social e política dos envolvidos.

Portanto, cumpre aqui asseverar, que a ação de formação em EJA dirigida aos Gestores e as Agentes Prisionais do Ceará, executadas ao longo dos períodos citados, deve, necessariamente, estar relacionada à proposta de formação dos Professores do Sistema Prisional cearense, que ora é apresentada. Os principais elos teóricos de ligação entre as duas ações de formação estão centrados nos seguintes aspectos:

$>$ Fortalecimento da temática de EJA nas prisões: em ambos os casos, o foco foi a EJA, enquanto modalidade educacional que contempla segmentos desassistidos social e educacionalmente, e que se encontram inseridos no ambiente prisional.

$>$ Complementaridade entre as formações: houve, de forma clara e inequívoca, complementaridade das ações formativas, visto que o público alvo de ambas é formado por profissionais que atuam no sistema prisional.

Educação \& Realidade, Porto Alegre, v. 38, n. 1, p. 179-204, jan./mar. 2013. 185

Disponível em: <http://www.ufrgs.br/edu_realidade> 
> Indução à reflexão e ao conhecimento mútuo: as ações de formação têm permitido aos gestores, aos agentes prisionais e aos professores repensarem suas visões acerca do papel da educação no sistema prisional; suas atuações laborais; suas ações profissionais e cidadãs; bem como as suas visões de educação e de sociedade, através da constante reflexão sobre a ação.

> Indução à partilha de experiências e de conhecimentos: ao se ressaltar a formação dos profissionais do sistema prisional, se está sinalizando que esta é uma atividade relevante para a práxis laboral, Ademais, se está corroborando a extrema relevância da partilha de experiências e de conhecimentos adquiridos ao longo do exercício profissional.

> Indução à cooperação: como resultado da partilha de experiências e de conhecimentos, haverá a possibilidade de se iniciar maior cooperação entre as partes, com vistas à transformação das relações pessoais, dos papeis sociais e educacionais, bem como do próprio ambiente de trabalho.

Do ponto de vista operacional, há que serem ressaltados dois momentos de partilha de experiência, vislumbrados pelos organizadores das propostas de formação:

> Participação nos ciclos de palestras: durante ambas as formações ocorreram momentos nos quais palestrantes abordam temáticas diretamente vinculadas à EJA nas prisões.

> Tutoria na Elaboração dos Trabalhos de Conclusão de Curso (TCC): durante a fase de elaboração dos TCC haverá a tutoria dos quase 140 professores que estão sendo formados. É o momento de induzir à partilha de conhecimentos e de experiências, à reflexão conjunta e à cooperação entre as partes. Vislumbra-se, assim, o nascimento de novas relações laborais e interpessoais entre estes atores do sistema prisional.

\section{Supostos Teóricos da Proposta de Formação do Professor do Sistema Prisional do Ceará}

A educação prisional pode contribuir com a reinserção social dos presos. Contudo, não será qualquer proposta educacional que proporcionará benefícios reais, visto que o ensino no sistema penitenciário tem sido oferecido como se fosse uma escola regular, com o único intuito de alfabetizar e diplomar os alunos presos (Serrado Júnior, 2009).

O fato de se garantir o direito constitucional à educação não assegura de modo mecanicista a (re)inserção do aluno preso no mercado de trabalho. Nesse sentido, é preciso compreender a Educação como processo de formação, que possa aproximar o sujeito do seu pleno potencial enquanto ser humano. Assim, deste ponto inicial, pode-se chegar à compreensão de uma educação reflexiva e restauradora do potencial humano em sua plenitude. 
Nesse sentido, pode-se partir de uma constatação histórica: as poucas oportunidades que nos foram oferecidas para propor mudanças educacionais significativas acabaram sucumbindo a especulações financeiras e políticas firmadas por negociatas especulativas que não tinham o menor comprometimento com o popular, com a massa, com o povo brasileiro. Igualmente, a Educação oferecida no sistema penitenciário sofre do mesmo mal (Serrado Júnior, 2009). Portanto, há que se estar atento a estes empecilhos, de modo a evitá-los ou neutralizá-los na proposta de formação.

Em segundo lugar, a possibilidade de elevação dos alunos presos à categoria de cidadãos ativos, críticos e reflexivos precisa ser entendida como reflexo da proposta formativa, bem como da atuação dos professores formadores. Para tal faz-se necessário desenvolver uma perspectiva teórica que redefina a referida situação dos aprendizes, fornecendo, assim, as bases de uma visão alternativa de Educação no sistema penitenciário. Como asseverou Giroux (1997):

\begin{abstract}
Desejo argumentar que uma forma de repensar e reestruturar a natureza da atividade docente é encarar os professores como intelectuais transformadores [...] É importante enfatizar que os professores devem assumir responsabilidade ativa pelo levantamento de questões sérias acerca do que ensinam, como devem ensinar, e quais são as metas mais amplas pelas quais estão lutando (p. 161).
\end{abstract}

Sendo assim, cabe aos professores tomarem consciência do seu potencial como estudiosos e profissionais ativos, reflexivos e intelectuais, de modo a demonstrar aos seus alunos que Educação no sistema prisional tem como função não somente a escolarização (alfabetização de adultos e/ou remição de pena), mas compreender os aspectos econômicos, sociais e culturais que estão intimamente atrelados ao poder e ao controle (do indivíduo e da sociedade).

Portanto, caberá aos professores conscientizar os seus alunos que estar na prisão não é opção de vida, mas circunstância advinda da marginalização que foi e ainda é imposta por políticas públicas inadequadas e desconexas da realidade. Sob esta ótica, o professor formador deve se entender como condutor da liberdade vinculada à consciência, à reflexão sobre a vida, sobre a cidadania e sobre a dignidade que foi negada, mas que é possível de ser reconquistada.

$\mathrm{O}$ último aspecto a ser ressaltado diz respeito à formação específica para os servidores do sistema prisional, neste caso singular para os professores. A proposta de formação que ora se apresenta buscará a atitude reflexiva, tanto na prática pedagógica do professor quanto na formação do educando. Como asseverou Shon (2000) ao professor cabe conceber os problemas e as situações do local onde se pretende lecionar, determinar características observáveis, interpor a ordem que tentará impor e as linhas que serão efetivadas para a superação do paradigma vigente, para além da educação formal. 
Ao pretender-se induzir mudanças substantivas sobre os indivíduos componentes do sistema prisional, há que se ter consciência de que ela depende dos posicionamentos teóricos tomados hoje. A reflexão deve, portanto, permear a atuação do professor que atua no sistema prisional, por conta da especificidade educacional, que busca a reinserção de alunos presos na sociedade. Portanto, o ponto de partida de qualquer atividade no sistema prisional é a conscientização do formando frente à realidade social. O formando deve ter clareza acerca dos fatores que levaram a sociedade a adquirir as características atuais. Sendo assim, sob essa perspectiva teórica foi delineada a proposta curricular do Curso de Especialização para Professores do Sistema Prisional do Ceará, na área de Educação de Jovens e Adultos (EJA), conforme, a seguir, detalhada.

\section{Base Legal da Proposta do Curso de Especialização}

Inicialmente, há que se partir da compreensão de que a EJA é uma modalidade educacional que possui suas especificidades, e a partir delas deve organizar-se. A aplicação da função equalizadora exposta nas Diretrizes Curriculares para EJA (Parecer CEB 11/2000) recomenda a reparação corretiva da reentrada no sistema educacional dos sujeitos que tiveram interrupção de estudos, pela repetência, pela falta de escolas, pelas desiguais oportunidades de permanência ou por outras condições adversas.

Além dos aspectos provenientes das Diretrizes Curriculares da EJA, baseamo-nos no que vem sendo afirmado em documentos internacionais dos quais o Brasil é signatário, tais como: a Declaração de Hamburgo (V Confintea) e o Marco de Belém (VI Confintea) que preconizam o estímulo à oportunidade de aprendizagem a todos, em particular, aos marginalizados e excluídos; o incentivo à participação, inclusão e equidade, combatendo os efeitos cumulativos de múltiplas desvantagens, através da inclusão como via para o desenvolvimento humano, social e econômico, contribuindo para o convívio digno e humano. Outro compromisso assumido no Marco de Belém (VI Confintea) está contido na recomendação para a qualidade das ações educacionais, que prevê:

Fomentar uma cultura de qualidade da aprendizagem de adultos requer relevância de conteúdo e metodologias de ensino, analises centradas nas necessidades do aluno, aquisição de competências e conhecimentos múltiplos, profissionalização de educadores, enriquecimento de ambientes de aprendizagem e o empoderamento de indivíduos e comunidades ${ }^{3}$.

Este compromisso está diretamente relacionado a um dos objetivos do nosso curso que é elaborar uma proposta pedagógica específica para os professores do Sistema Penitenciário. As ações da formação estarão pautadas nas Diretrizes da Educação do Sistema Penitenciário, 
que asseveram que o as prisões são, por natureza, espaços educativos, implicando em que os todos que atuam em Unidades Prisionais são potenciais educadores. Ademais, os futuros formandos deverão conceber a educação como processo capaz de transformar o potencial dos reclusos, em termos de competências, capacidades e habilidades, criando condições para que cada indivíduo molde sua identidade, e compreenda-se como um ser social, capaz de contribuir com as mudanças necessárias ao país (Villela Pereira; De La Fare, 2011).

\section{Elaboração da Proposta de Formação a partir do Diagnóstico das Necessidades e dos Interesses dos Professores}

A primeira ação da Equipe Pedagógica responsável pela organização e elaboração da Proposta de Formação de Professores do Sistema Prisional do Ceará consistiu em reunir-se com o grupo de professores, com o intuito de solicitar a escolha das áreas nas quais houvesse maior interesse e necessidade de formação, dentre as quais, foram identificadas:

- Temas associados à Educação de Jovens e Adultos (EJA): Legislação e didática em EJA; Currículo de EJA; Estrutura de Funcionamento de EJA Fundamental e Médio; Alfabetização em EJA; Educação Popular; Pedagogia de Paulo Freire;

- Temas associados à Educação Prisional: Direitos Humanos; Educação Prisional no Brasil; Introdução ao Direito Penal e a LEP;

- Temas associados às Ciências Humanas: Relações Humanas; Avaliação; Psicologia; Psicopedagogia; Sociologia da Educação; Filosofia da Educação; Antropologia Cultural; Metodologia da Pesquisa.

Com base no exposto, bem como em respeito às exigências da Resolução do Fundo Nacional de Desenvolvimento da Educação (FNDE/ CD) no 48 de novembro de 2008; as Diretrizes Curriculares para EJA (011/2000); as Diretrizes Nacionais para oferta de educação nos Estabelecimentos Penais (aprovada em 09 março 2010) e a Declaração de Hamburgo e Marco de Belém, elaborou-se uma proposta de Matriz Curricular para a Formação de Professores do Sistema Prisional do Ceará, ao nível de Especialização, conforme explicitada a seguir.

\section{Matriz Curricular do Curso de Especialização em EJA para Professores do Sistema Prisional}

O curso em foco, que recebe financiamento da Secretaria de Educação Continuada, Alfabetização, Diversidade e Inclusão (SECADI), do Ministério da Educação (MEC), é composto por três Módulos de Disciplinas, a saber:

Educação \& Realidade, Porto Alegre, v. 38, n. 1, p. 179-204, jan./mar. 2013. 
a) Módulo Básico: composto por disciplinas presenciais dedicadas a abordar o desenvolvimento dos fundamentos, princípios e estratégias metodológicas da Educação de Jovens e Adultos (EJA). O Módulo Básico terá carga horária total de 180 horas, distribuídas conforme as seis disciplinas abaixo referidas:

1 - Sujeitos da Educação de Jovens e Adultos (EJA) - 30 horas. EMENTA: Documento brasileiro preparatório para a VI Confintea; Declaração de Hamburgo; Marco de Belém; Educação para Diversidade e Cidadania. OBJETIVO: Aprofundar estudos em documentos oficiais e pesquisas que abordem os sujeitos da EJA, considerando suas especificidades.

2 - Educação de Jovens e Adultos (EJA) e a Pedagogia de Paulo Freire - 30 horas. EMENTA: Conceitos básicos da EJA; Proposta Curricular baseada na Pedagogia Freiriana. OBJETIVO: Refletir sobre a educação de jovens e adultos a partir de uma visão dialógica de educação.

3 - Legislação e Políticas Públicas de Educação de Jovens e Adultos (EJA) - 30 horas. EMENTA: Lei de Diretrizes e Bases da Educação Nacional (9.394/96); Diretrizes Curriculares para Educação de Jovens e Adultos (Resolução 011/2000); Diretrizes para Educação no Sistema Penitenciário (aguardando publicação). OBJETIVO: Estudar a legislação relacionada à EJA e as políticas relacionadas à Educação no Sistema Prisional.

4 - Educação de Jovens e Adultos (EJA) e o mundo do trabalho-30 horas. EMENTA: Sujeitos de direitos e de necessidades; integração do educando trabalhador à proposta político-pedagógica; o trabalho como produção humana. OBJETIVOS: Refletir sobre o trabalho como princípio educativo; conhecer as principais ações de formação profissional executadas em Unidades Prisionais brasileiras; estudar casos exitosos.

5 - Estratégias metodológicas para a Educação de Jovens e Adultos (EJA) - 30 horas. EMENTA: Prática x práxis; estudo de práticas desenvolvidas em salas de EJA do MOVA, do MST, da Educação Popular, da Educação em Unidades Prisionais; refletir sobre a prática do educador/cursista. OBJETIVOS: Discutir e refletir sobre as práticas didáticas na EJA, numa relação entre teoria e prática; elaborar projetos didáticos para desenvolvimento da escolarização nas prisões.

6 - Fundamentos teóricos da formação de Professores em Educação de Jovens e Adultos (EJA) - 30 horas. EMENTA: Avanços e desafios na formação do educador de EJA; Diretrizes que norteiam a formação inicial e continuada dos educadores de EJA; Currículo da formação de educadores de EJA. OBJETIVOS: Conhecer aspectos fundantes da formação de educadores de EJA e dos demais trabalhadores do sistema prisional. Levantar aspectos próprios do sistema prisional importantes de serem levados em consideração 
na formação dos educadores e demais trabalhadores do sistema prisional.

b) Módulo Específico: composto por disciplinas presenciais dedicadas a abordar os conhecimentos voltados à Educação de Jovens e Adultos (EJA) no sistema prisional, de forma a contemplar as atividades do cotidiano carcerário, as experiências dos professores, bem como a realidade na qual atuam os referidos profissionais alvos da ação. O Módulo Específico terá carga horária total de 180 horas, distribuídas conforme as sete disciplinas abaixo referidas:

7 - Elementos Históricos da Educação de Jovens e Adultos (EJA) no Sistema Prisional-30 horas. EMENTA: Histórico da educação no sistema prisional; síntese dos seminários nacionais de educação nas prisões; Programa Educando para Liberdade; Avaliação do Programa Educando para Liberdade. OBJETIVO: Conhecer o contexto histórico da educação de jovens e adultos no Sistema Prisional compreendendo os ganhos conquistados nos últimos anos.

8 - Educação de Jovens e Adultos (EJA) no Sistema Prisional: Fundamentos da Legislação Penal e Educacional-30 horas. EMENTA: Estudo da Lei de Execuções Penais, das Diretrizes Nacional de Educação. OBJETIVOS: Conhecer a Legislação relacionada à pena e à educação no Sistema Prisional, traçando um paralelo crítico com a realidade concreta das prisões.

9 - Direitos Humanos e Educação de Jovens e Adultos (EJA) no Sistema Prisional - 30 horas. EMENTA: Direitos humanos nas prisões: base legal. A ética nas prisões: bases conceituais. A LEP e os direitos humanos: dados da realidade brasileira. Reeducação da pessoa presa. Respeito aos Direitos Humanos da pessoa presa. A situação penitenciária do Ceará. Princípios filosóficos e históricos que orientam internacionalmente a prisão. Elementos internacionais e nacionais relativos a sanção de privação de liberdade. OBJETIVO: Proporcionar conhecimentos mínimos sobre os direitos humanos das pessoas presas. Construir uma visão crítica sobre o sistema prisional com respeito aos direitos humanos das pessoas presas. Discutir a relação entre direitos humanos e direito à educação.

10 - Humanização das Prisões e Educação de Jovens e Adultos (EJA) - 30 horas. EMENTA: Elementos normativos contidos na Constituição Federal, na Declaração Universal dos Direitos Humanos da ONU, no Pacto de São José da Costa Rica (Decreto No 678/92), nas Regras Mínimas para o tratamento do preso no Brasil (Resolução No 14/94, do CNPCP). Direitos Humanos. O Preso como pessoa. Violação dos Direitos Humanos nos presídios. Papel institucional do Estado na defesa dos Direitos Humanos. Religião e prisão. Do direito de culto. OBJETIVO: Proporcionar conhecimentos mínimos acerca da necessidade de humanizar 
as prisões brasileiras. Discutir de modo crítico a realidade do sistema prisional cearense, no que tange à humanização dos seus espaços. Discutir a necessidade de se repensar as relações entre os profissionais das prisões, e entre estes e as pessoas presas, de modo a fortalecer a humanização no sistema prisional.

11 - Gestão dos Espaços Pedagógicos destinados à Educação de Jovens e Adultos (EJA) no Sistema Prisional-30 horas. EMENTA: Aspecto preconizado em documentos oficiais sobre gestão dos espaços pedagógicos nas unidades prisionais; transposição do saber na educação popular. OBJETIVOS: Aprofundar estudos a partir de experiências já registradas e da realidade das unidades prisionais de origem dos educadores e trabalhadores do sistema. 12 - Educação de Jovens e Adultos (EJA) e Educação Especial no Sistema Prisional-15 horas. EMENTA:Alunos com necessidades especiais nas prisões. Tipologia das necessidades especiais. Papel do professor ao ter alunos com necessidades especiais. Direitos dos alunos com necessidades especiais. OBJETIVO: Proporcionar conhecimentos mínimos sobre os alunos com necessidades especiais nas prisões. Conhecer os procedimentos didáticos orientados a este tipo de aluno.

13 - Educação de Jovens e Adultos (EJA) e o Mundo do Trabalho: Perspectivas para a Formação Profissional - 15 horas. EMENTA: Os jovens e adultos no mundo do trabalho; os contextos nacional e regional do mundo do trabalho; processo histórico-sóciocultural de humanização (relação homem-natureza, sociedade e cultura); relações entre sociedade e educação; sociedade e escola; sociedade e trabalho; trabalho como princípio educativo; educação e geração de trabalho e renda na perspectiva do desenvolvimento sustentável; mundo do trabalho como eixo gerador da produção de outros conhecimentos. OBJETIVOS: Descrever e discutir o mundo do trabalho e seus princípios aplicados à EJA.

\section{Requisitos Complementares do Curso de Especialização}

Em caráter complementar aos dois módulos iniciais, porém obrigatório, está previsto o Módulo de Formação em Pesquisa, conforme abaixo especificado.

c) Módulo de Formação em Pesquisa: será destinado à formação inicial dos aprendizes nas atividades da pesquisa científica no Sistema Prisional, de modo a promover a adequada execução de um Trabalho de Conclusão de Curso (TCC) pautado, integralmente, no planejamento e no desenvolvimento de um projeto de pesquisa educacional no ambiente carcerário.

Neste módulo incentivaremos o olhar reflexivo sobre a prática de sala de aula, com o registro dos planejamentos e resultados obtidos, 
registros sobre como se dá a transposição dos saberes, verificação das necessidades a partir da prática, criar momentos com os educandos, de forma a trazer a contribuição dos mesmos para a proposta pedagógica, adotando na formação a pesquisa como princípio educativo - "Escola e pesquisa um encontro possível”. Para tal, duas disciplinas serão ministradas, num total de 60 horas aula, conforme descrição abaixo:

14 - A Pesquisa Científica e a EJA: Elementos Básicos - 30 horas. EMENTA: A pesquisa educacional: modelos, potencialidades e limitações. As potencialidades da pesquisa educacional no âmbito do Sistema Prisional. A pesquisa documental, a pesquisa de campo (correlacional e quase-experimental). Tipologia de instrumentos de pesquisa: questionários, roteiros de entrevistas (estruturada, semiestruturada e aberta) e roteiros de observação. $\mathrm{O}$ uso de indicadores educacionais. OBJETIVOS: Proporcionar cabedal de informações para a execução de pesquisas no sistema prisional. Discutir os principais tipos de instrumentos de pesquisa e suas potencialidades. Proporcionar conhecimentos mínimos sobre a geração e o uso de indicadores educacionais. 15 - O Trabalho de Conclusão de Curso (TCC): fundamentos para a sua elaboração e execução - 30 horas. EMENTA: O Relatório de Pesquisa Científica: princípios técnicos e acadêmicos. As normas técnicas da ABNT. Princípios básicos da redação acadêmica. OBJETIVO: Proporcionar conhecimentos mínimos para a geração de uma monografia de final de curso, com base nas normas técnicas da ABNT e nos princípios de cientificidade.

A partir do exposto, o objetivo deste trabalho é apresentar os resultados das ações avaliativas dos processos de formação dos 121 Professores do Sistema Prisional do Ceará, atualmente em execução.

\section{Avaliação da Formação dos Professores do Sistema Prisional do Ceará: fundamentos teóricos}

Na vasta literatura acerca da avaliação educacional, há inúmeros intentos de classificação das investigações de cunho avaliativo (Shadish Jr.; Cook; Levinton, 1991). Conforme Capucha, Almeida, Pedroso e Vieira da Silva (1996), tais investigações podem ser organizadas em pelo menos quatro tipos, a saber:

a) Avaliação ex-ante: consiste na identificação de necessidades e na execução de estudos de factibilidade. Referidas ações devem orientar a formulação e o desenvolvimento de uma atividade, um programa ou uma política. Inclui a definição de objetivos, o âmbito de aplicação, a caracterização dos beneficiários e o atendimento de necessidades (Pedrozo, 2007).

b) Acompanhamento e monitoramento: em geral, busca identificar o grau de adequação entre o planejado e o executado (Blankenberg,

Educação \& Realidade, Porto Alegre, v. 38, n. 1, p. 179-204, jan./mar. 2013. 
1995). Trata-se, assim, de ação que visa avaliar a eficiência. Nesse âmbito, as atividades de monitoramento permitem intervir no processo de execução da atividade, programa ou política, corrigindo os rumos cada vez que desvios são detectados. Na maior parte das vezes, referida intervenção exige iniciativa, criatividade e soluções alternativas aos entraves surgidos durante o processo executivo (Carvalho; White, 1995).

c) Avaliação formativa (avaliação de processos): tem por objetivo identificar o grau de coerência e de perfeição das atividades (ou dos processos) que estão sendo executadas (Rosales, 1984). A essência do trabalho do avaliador é acompanhar, observar e diagnosticar os processos inerentes ao alcance dos objetivos do programa, com vistas ao aprimoramento destes, em muitos casos, concomitantemente à sua execução. Este acompanhamento inclui o diagnóstico das eventuais falhas dos instrumentos, procedimentos, conteúdos e métodos, bem como da adequação da atividade, do programa ou da política, ao público-alvo (Scriven, 1994).

d) Avaliação somativa, de resultado ou ex-post: envolve estudos focados nos resultados de uma ação, atividade, programa, curso ou algo similar. Assim, o objeto é o produto ou a consequência tangível de uma ação planejada (Scriven, 1994).

Nesse âmbito, a avaliação do processo de formação dos Professores do Sistema Prisional permitirá o diagnóstico, o planejamento de ações de aprimoramento e a tomada de decisões por parte dos gestores e dos formuladores de programas e de políticas públicas, com vistas à adequação destas últimas ao público usuário, consoante às idéias de Andriola (1999). Desse modo, e para finalizar, cabe recorrer a Therrien e Sobrinho $(1983 ; 1984)$ para quem a avaliação deve revelar:

[...] não apenas o somatório de realizações [da atividade, do programa, da política], mas, sobretudo, o efeito ou impacto de sua presença e atuação no contexto social que lhe dá razão de ser. [...] Ao mesmo tempo em que contribui para a unificação efetiva das partes num todo coerente e atuante, a avaliação consolida os empenhos de participação, porque reconhece os princípios da democracia e da responsabilidade conjunta [de usuários, de executores, de gestores e de formuladores] (p. 19).

\section{Avaliação do Curso de Especialização em EJA para Professores do Sistema Prisional do Ceará}

Durante a realização do Curso de Especialização em EJA para Professores do Sistema Prisional do Ceará têm sido empregados procedimentos para a avaliação de processos, para se garantir qualidade mínima à formação vislumbrada (Andriola et al., 2009; Berk; Rossi, 1990), cujos resultados são apresentados a seguir. 


\section{Avaliação de processos (formativa): a atuação docente}

A avaliação de processos ou formativa teve como objetivo assegurar qualidade mínima à formação dos Professores do Sistema Prisional do Ceará a partir da atuação dos docentes formadores, em sala de aula. Para tal, centrou-se na avaliação do professorado, visto que ser este o principal responsável pela qualidade da formação dos alunos (Gomes Andriola, 2011). Com base em critérios definidos a priori que constituíram um questionário específico, os professores formadores foram, então, avaliados pelos alunos das duas turmas, conforme ilustram os dados da Tabela 1.

Tabela 1 - Resultados da avaliação de um professor formador pelos respectivos alunos

\begin{tabular}{|c|c|c|c|}
\hline \multirow[b]{2}{*}{ Aspectos avaliados da atuação docente } & \multicolumn{3}{|c|}{$\%$ de respostas positivas } \\
\hline & $\begin{array}{c}\text { Turma } \\
\mathrm{A}\end{array}$ & $\begin{array}{c}\text { Turma } \\
\text { B }\end{array}$ & Média \\
\hline $\begin{array}{l}\text { 1. Esclareceu o significado e a importância } \\
\text { da disciplina para o curso }\end{array}$ & 85 & 91 & 88 \\
\hline $\begin{array}{l}\text { 2. Demonstrou organização e sequência } \\
\text { lógica ao ministrar os conteúdos progra- } \\
\text { máticos }\end{array}$ & 86 & 84 & 85 \\
\hline $\begin{array}{l}\text { 3. Usou linguagem acessível para melhorar } \\
\text { a compreensão do conteúdo pelos alunos }\end{array}$ & 82 & 86 & 84 \\
\hline $\begin{array}{l}\text { 4. Utilizou procedimentos didáticos ade- } \\
\text { quados aos objetivos da disciplina }\end{array}$ & 85 & 81 & 83 \\
\hline $\begin{array}{l}\text { 5. Dinamizou as aulas, promovendo ativi- } \\
\text { dades que estimularam a participação dos } \\
\text { alunos }\end{array}$ & 83 & 80 & 81 \\
\hline $\begin{array}{l}\text { 6. Orientou com clareza os trabalhos soli- } \\
\text { citados }\end{array}$ & 89 & 91 & 90 \\
\hline $\begin{array}{l}\text { 7. Estabeleceu relação entre teoria e prática, } \\
\text { respeitando as especificidades da disciplina }\end{array}$ & 89 & 92 & 90 \\
\hline $\begin{array}{l}\text { 8. Evidenciou domínio dos conteúdos com- } \\
\text { ponentes da disciplina ministrada }\end{array}$ & 96 & 96 & 96 \\
\hline $\begin{array}{l}\text { 9. Manteve adequada postura ético-profis- } \\
\text { sional na sala de aula }\end{array}$ & 90 & 92 & 91 \\
\hline 10. Foi pontual & 92 & 88 & 90 \\
\hline 11. Foi assíduo & 93 & 94 & 93 \\
\hline $\begin{array}{l}\text { 12. Manteve bom relacionamento com os } \\
\text { discentes }\end{array}$ & 92 & 91 & 91 \\
\hline $\begin{array}{l}\text { 13. Estabeleceu, de forma clara, os critérios } \\
\text { para avaliação do aprendizado discente }\end{array}$ & 82 & 82 & 82 \\
\hline
\end{tabular}

Fonte: Coordenação do Curso de Especialização em EJA para Professores do Sistema Prisional do Ceará. 
Conforme as informações, a dinamização das aulas e a promoção de atividades estimuladoras da participação dos alunos foi o aspecto com pior avaliação, pois obteve, em média, $81 \%$ de respostas positivas dos alunos. Por outro lado, o domínio dos conteúdos componentes da disciplina ministrada foi o aspecto do professorado com melhor avaliação, pois obteve, em média, $96 \%$ de respostas positivas dos alunos.

De modo geral, conforme os resultados das avaliações dos alunos das cinco turmas, os professores foram muito bem valorados, denotando a elevada qualidade do processo de formação dos Agentes Prisionais, na perspectiva dos próprios aprendizes.

\section{Avaliação de Processos (formativa): os ciclos de palestras}

Outros aspectos inerentes à formação dizem respeito às várias atividades componentes do Curso de Especialização em EJA, dentre as quais: a qualidade dos espaços pedagógicos, a organização curricular e o horário das aulas; a gestão pedagógica do curso; a relevância dos conteúdos abordados e das palestras ministradas; a excelência dos professores e dos palestrantes; os impactos da formação sobre a atuação profissional e sobre o sistema prisional. Desse modo, foram obtidos 120 questionários preenchidos pelos alunos ao final do I Ciclo de Palestras ocorrido entre 04 e 05 de agosto de 2011, no Auditório Prof. Valnir Chagas (FACED/UFC), cujas informações foram consideradas válidas. No Gráfico 1, constam as respostas válidas dos 120 alunos sobre a relevância do Curso de Especialização em EJA para a prática cotidiana dos Professores do Sistema Prisional do Ceará.

Gráfico 1 - Relevância da formação para a prática profissional

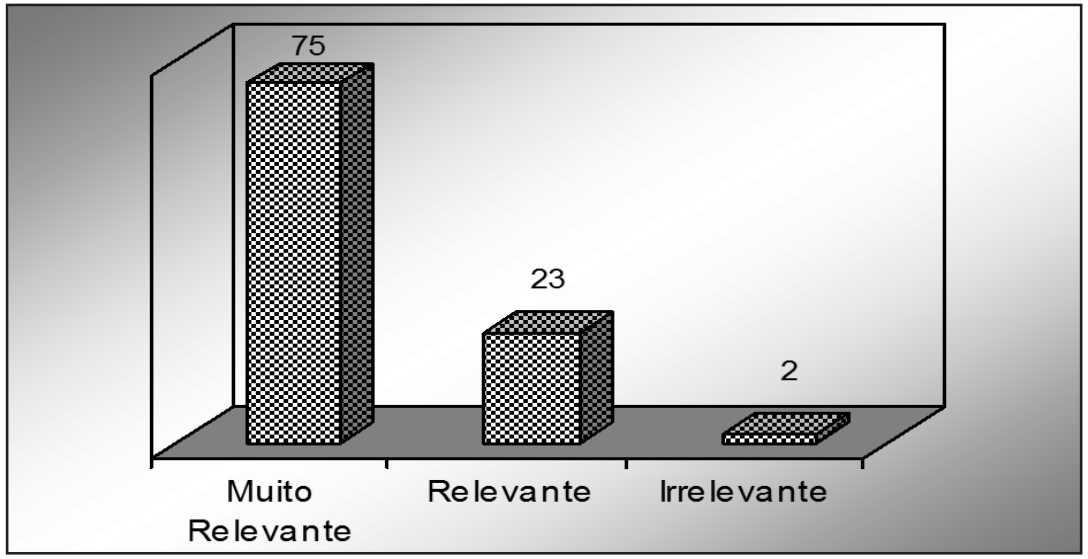

Fonte: Pesquisa direta. Elaborado pelos autores.

Como se observa, a ampla maioria dos alunos asseverou que a formação recebida através do Curso de Especialização em Educação de 
Jovens e Adultos (EJA) é muito relevante ou relevante para a sua prática profissional ( $98 \%$ ou $\mathrm{n}=118)$.

No Gráfico 2, a seguir, constam as respostas dos alunos sobre a relevância do curso para o exercício profissional e cidadão.

\section{Gráfico 2 - Relevância da formação para o exercício profissional e} cidadão

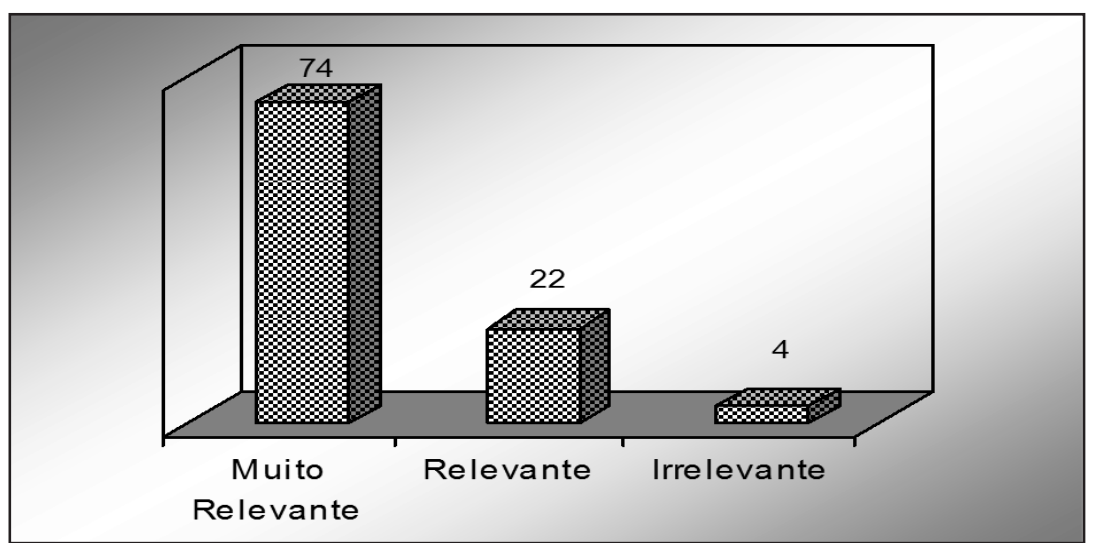

Fonte: Pesquisa direta. Elaborado pelos autores.

Conforme as informações, a ampla maioria dos alunos asseverou que a formação recebida através do Curso de Especialização em EJA é muito relevante ou relevante para o exercício profissional, bem como para a cidadania $(96 \%$ ou $\mathrm{n}=115)$.

O Gráfico 3, a seguir apresentado, contém as respostas dos alunos sobre a relevância dos conteúdos abordados no Curso de Especialização em EJA nas prisões.

Gráfico 3 - Relevância dos conteúdos abordados no Curso de Especialização em EJA nas prisões

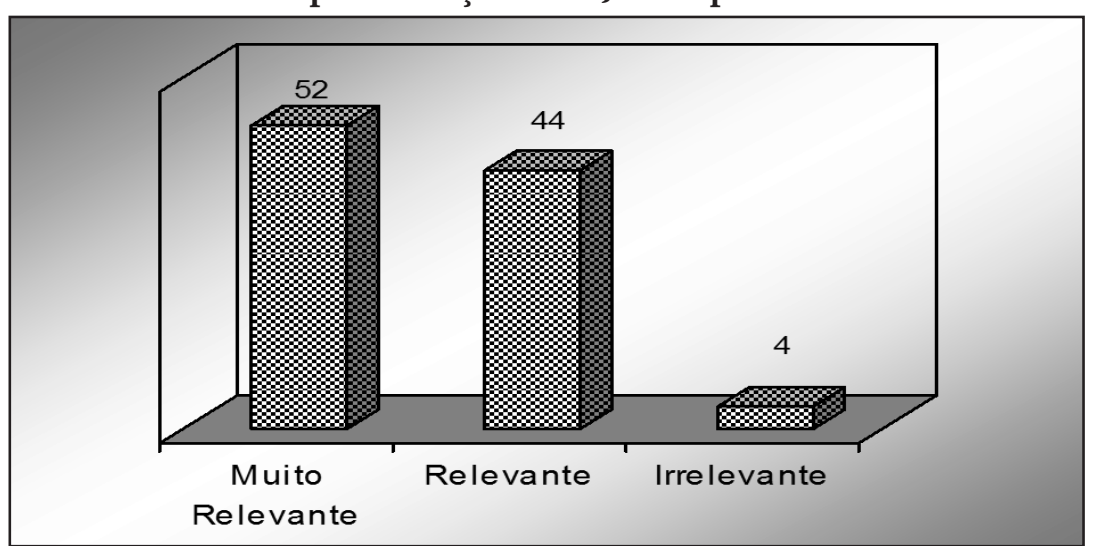

Fonte: Pesquisa direta. Elaborado pelos autores.

Educação \& Realidade, Porto Alegre, v. 38, n. 1, p. 179-204, jan./mar. 2013.

Disponível em: <http://www.ufrgs.br/edu_realidade> 
De acordo com os dados, a ampla maioria dos alunos crê que os conteúdos abordados nas disciplinas até aqui ministradas foram muito relevantes ou relevantes $(96 \%$ ou $n=115)$. No Gráfico 4 há a opinião dos alunos sobre as possíveis mudanças que se debaterão sobre o Sistema Prisional do Ceará, a partir da formação.

\section{Gráfico 4 - Magnitude de mudanças que poderão vir a ocorrer no Sistema Prisional do Ceará}

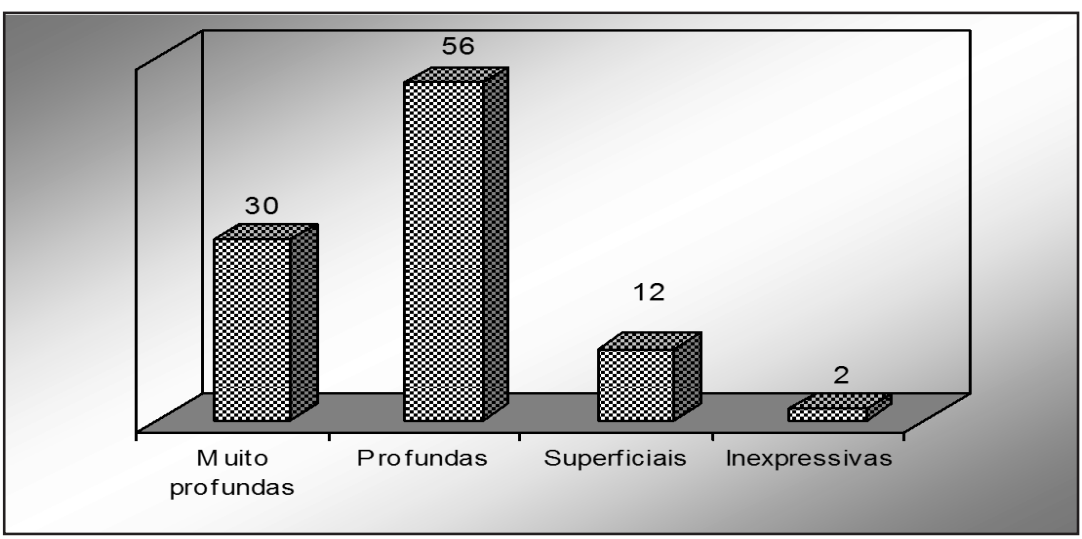

Fonte: Pesquisa direta. Elaborado pelos autores.

Como se pode ver, a ampla maioria dos alunos asseverou que as possíveis mudanças que poderão acometer o Sistema Prisional do Ceará, a partir do Curso de Especialização em EJA para Professores, serão de magnitude muito profunda ou profunda $(86 \%$ ou n $=103)$. No Gráfico 5 constam dados sobre a relevância de futuras ações de formação, destinadas aos Agentes e Gestores do Sistema Prisional do Ceará.

Gráfico 5 - Relevância de futuras ações de formação destinadas aos Agentes e Gestores do Sistema Prisional do Ceará

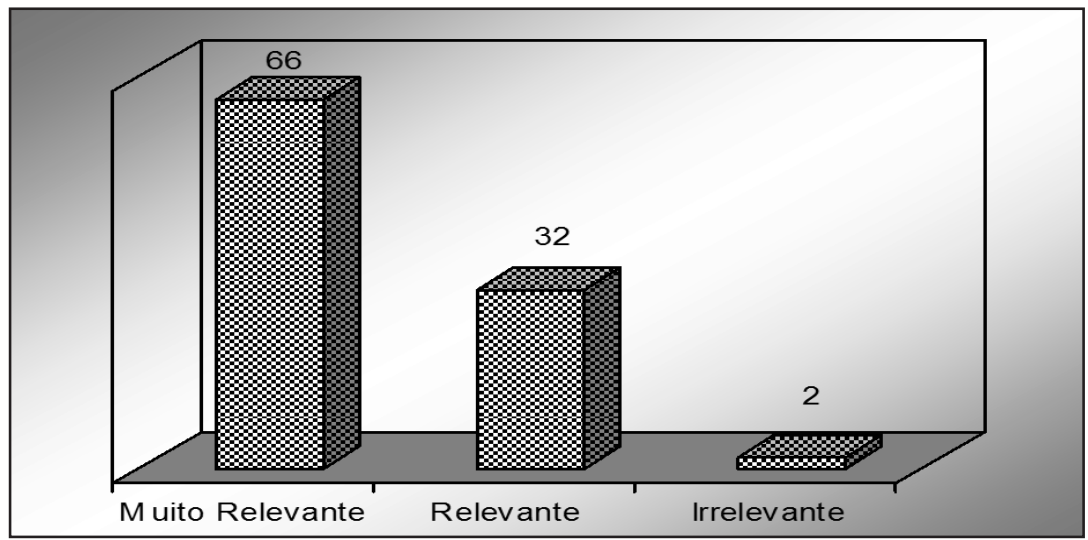

Fonte: Pesquisa direta. Elaborado pelos autores. 
Segundo as informações, a ampla maioria dos alunos asseverou que futuras ações de formação destinadas aos Agentes e aos Gestores Prisionais do Ceará serão muito relevantes ou relevantes $(98 \%$ ou $\mathrm{n}=118)$ para o próprio Sistema Prisional.

O Gráfico 6, abaixo, contém as respostas dos alunos sobre a qualidade da atuação dos professores formadores do Curso de EJA nas prisões.

Gráfico 6 - Qualidade da atuação dos professores do Curso de Especialização em Educação de Jovens e Adultos (EJA) nas prisões

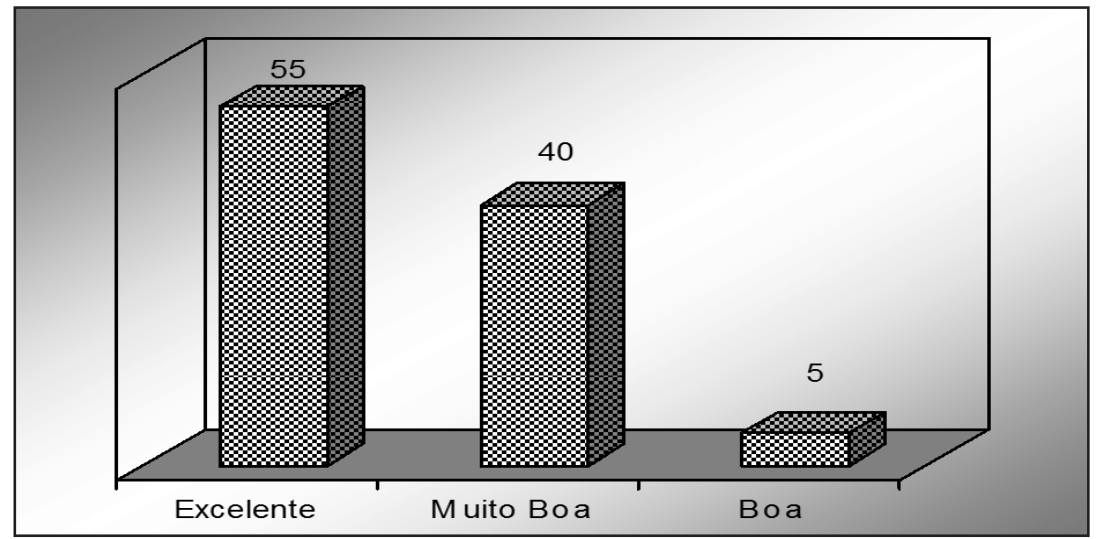

Fonte: Pesquisa direta. Elaborado pelos autores.

De acordo com os dados, a ampla maioria dos alunos asseverou que a atuação dos professores formadores no Curso de Especialização em EJA nas prisões tem sido excelente ou muito boa $(95 \%$ ou $\mathrm{n}=114)$. No Gráfico 7, abaixo, estão as opiniões dos alunos sobre a qualidade da gestão pedagógica do Curso de Especialização em EJA.

\section{Gráfico 7 - Qualidade da gestão pedagógica do Curso de} Especialização em EJA nas prisões

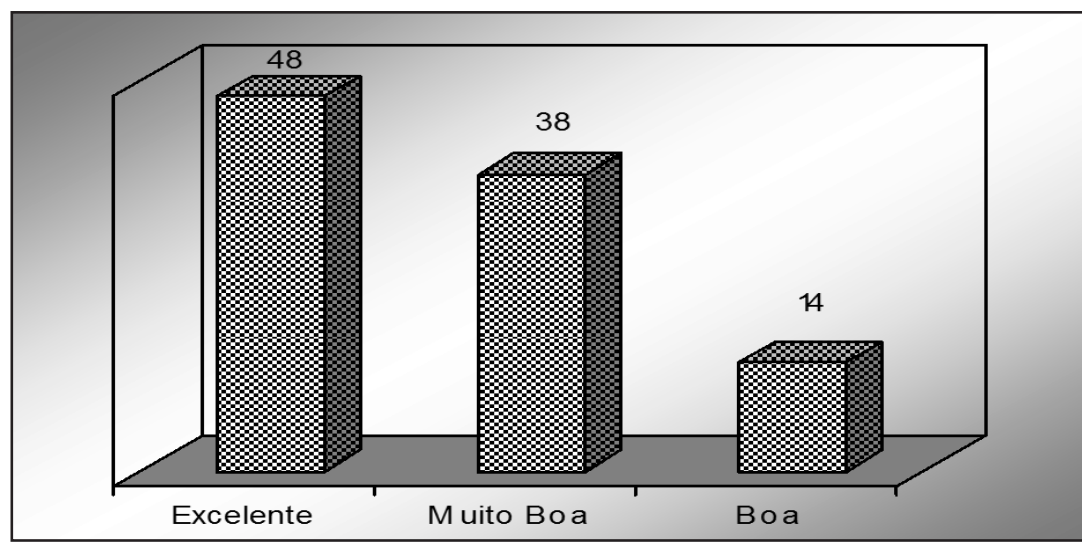

Fonte: Pesquisa direta. Elaborado pelos autores.

Educação \& Realidade, Porto Alegre, v. 38, n. 1, p. 179-204, jan./mar. 2013.

Disponível em: <http://www.ufrgs.br/edu_realidade> 
Como se pode observar, a ampla maioria dos alunos asseverou que a gestão pedagógica do Curso de Especialização em EJA nas prisões pode ser compreendida como excelente ou muito boa $(86 \%$ ou $\mathrm{n}=$ 103). No Gráfico 8 estão as respostas dos alunos sobre a qualidade das instalações físicas da Escola de Gestão Penitenciária e Ressocialização (EGPR), local onde ocorre o Curso de Especialização.

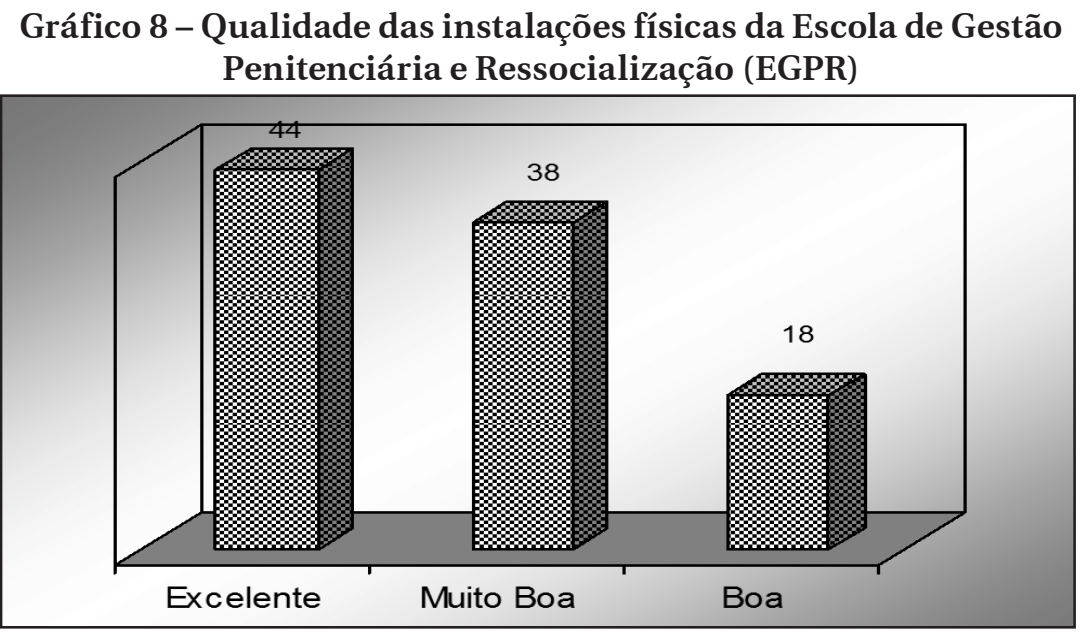

Fonte: Pesquisa direta. Elaborado pelos autores.

Conforme a ampla maioria dos alunos, as instalações físicas da Escola de Gestão Penitenciária e Ressocialização (EGPR) destinadas ao Curso de Especialização podem ser consideradas como excelentes ou muito boas $(82 \%$ ou $\mathrm{n}=98)$. No Gráfico 9 constam as respostas dos alunos sobre a adequação dos dias e horários das aulas.

Gráfico 9 - Adequação dos dias e horários das aulas do Curso de Especialização em Educação de Jovens e Adultos (EJA) nas prisões

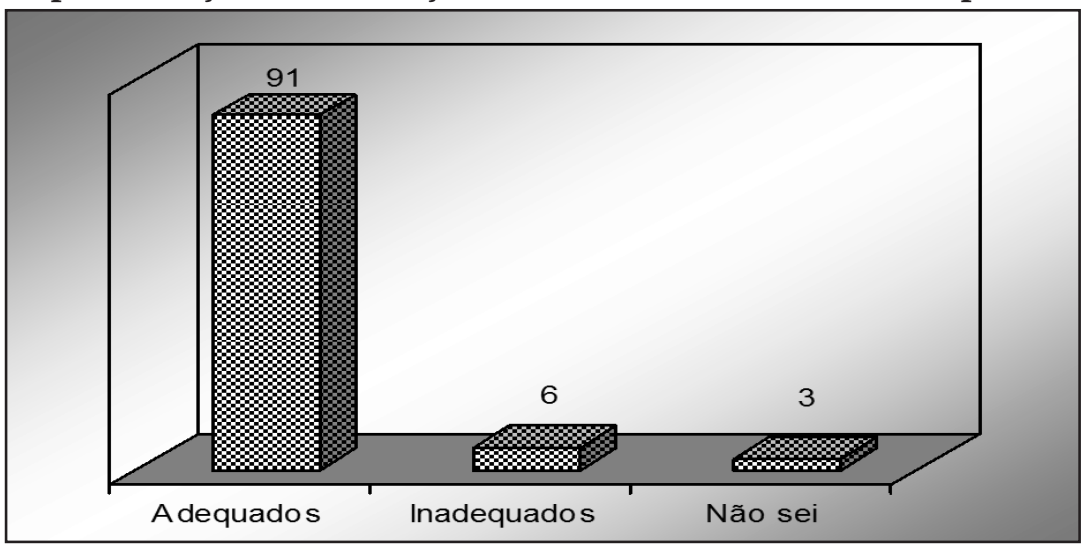

Fonte: Pesquisa direta. Elaborado pelos autores. 
De acordo com os dados, a ampla maioria dos alunos asseverou que os dias e horários de aulas do Curso de Especialização em Educação de Jovens e Adultos (EJA) nas prisões podem ser considerados como adequados $(91 \%$ ou $\mathrm{n}=109)$.

O Gráfico 10, abaixo, contém as respostas dos alunos sobre a relevância do I Ciclo de Palestras para a formação dos Professores do Sistema Prisional.

\section{Gráfico 10 - Relevância dos Ciclos de Palestras para a formação dos Professores}

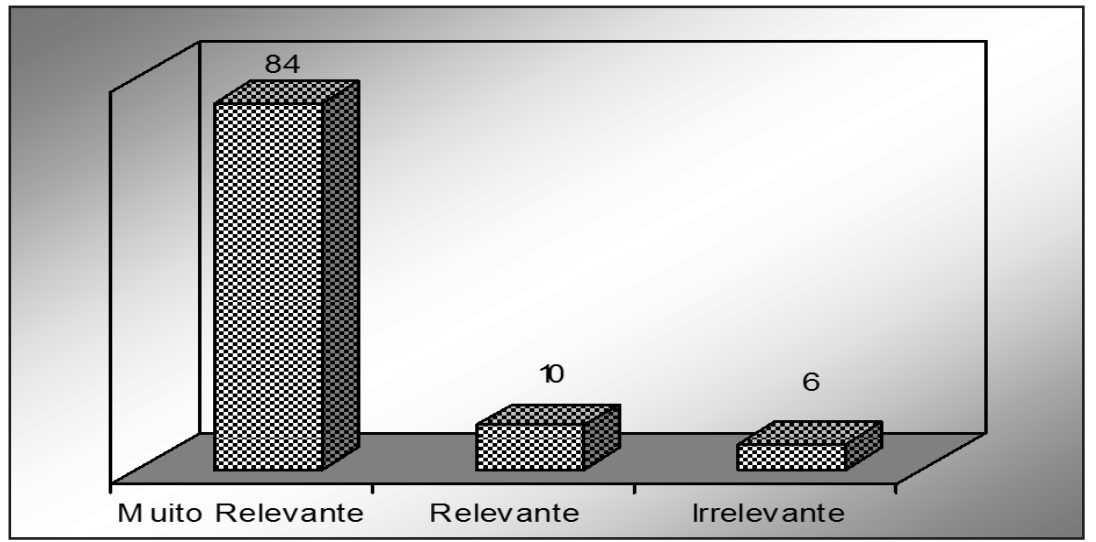

Fonte: Pesquisa direta. Elaborado pelos autores.

Conforme os dados, a ampla maioria dos alunos asseverou que o I Ciclo de Palestras componentes do Curso de Especialização em Educação de Jovens e Adultos (EJA) nas prisões pode ser considerado como muito relevante ou relevante $(94 \%$ ou $\mathrm{n}=112)$ para a formação do alunado.

\section{Considerações Finais}

De um modo geral se pode asseverar que as metas com vistas à formação de 120 Professores do Sistema Prisional do Estado do Ceará, na área de Educação de Jovens e Adultos (EJA) nas prisões, em nível de especialização (lato sensu), estão na direção adequada, conforme planejamento feito a priori. Não obstante, há alguns empecilhos a serem vencidos. Um deles diz respeito ao absenteísmo às aulas, que se tem revelado preocupante. Parece ser que, atingidos por ausência de ações de formação sistemática, os Professores do Sistema Prisional, em parcela não tão significativa, estão desacostumados ao ambiente escolar, à disciplina que deve pautar as ações pedagógicas, dentre outros aspectos que caracterizam a rotina acadêmica. Por estes e outros fatos, além das faltas constantes, há muitos casos de atraso às aulas, ocasionando perdas relevantes à formação vislumbrada, visto o impedimento destes

Educação \& Realidade, Porto Alegre, v. 38, n. 1, p. 179-204, jan./mar. 2013. 201 
Ações de Formação em EJA nas Prisões

alunos de participar de ações de interação com os colegas e com os professores formadores.

A coordenação do Curso de Especialização, bem como a gestão da Escola de Gestão Prisional e Ressocialização (EGPR/SEJUS/CE), em conjunto com os professores formadores, têm empregado mão de diferentes ações e estratégias, com vistas a diminuir as incidências desses casos. Dessa forma, alunos têm sido submetidos a sessões de aulas extras, de modo a repor a carga horária não cursada e, assim, ter acesso aos conteúdos pedagógicos não trabalhados durante a formação no Curso de Especialização em Educação de Jovens e Adultos (EJA).

Cabe destacar, por oportuno, que os dados resultantes da avaliação dos processos de formação do Curso de Especialização em EJA, sob a ótica dos discentes, apontaram para a excelência da atuação dos professores, bem como da gestão pedagógica, da infraestrutura física da EGPR, das palestras de profissionais da área de EJA nas prisões, dos conteúdos curriculares abordados nas várias disciplinas, dentre outros aspectos positivamente destacados.

Esta ação de formação em EJA, ademais de outras ações já executadas, em conjunto com pesquisas em andamento, confere ao Estado do Ceará o status de liderança regional. Compete a essa inteliigentia assegurar reflexões consistentes, pautadas em intercâmbios com profissionais de outros estados da federação e de outros centros universitários, bem como no uso de teorias válidas, amparadas em práticas duradoras, de modo a cultivar um ethos acadêmico favorável às visões inovadoras para as políticas de EJA nas prisões brasileiras.

Para finalizar, há que se realçar alguns aspectos que caracterizam o atual cenário prisional brasileiro, conforme ressaltaram Julião (2006), Santiago e Britto (2006), Graciano e Schilling (2008): população carcerária formada basicamente por jovens, pobres, homens, com baixo nível de escolaridade, com mais da metade dos presos com menos de trinta anos, com profissionais ansiosos por formação. Essa realidade deverá ser alvo de transformações substanciais, através da poderosa ação proporcionada pela Educação. Nesse âmbito, cabe acentuar sábia frase de um dos mais ilustres educadores brasileiros de todos os tempos: o pernambucano Paulo Reglus Neves Freire (1921-1997): a educação sozinha não transforma a sociedade, sem ela tampouco a sociedade muda ${ }^{4}$.

Recebido em 16 de julho de 2012 Aprovado em 29 de dezembro de 2012

\section{Notas}

1 Projeto financiado pela Secretaria de Educação Continuada, Alfabetização, Diversidade e Inclusão (SECADI), do Ministério da Educação (MEC), e pelo Conselho Nacional de Desenvolvimento Científico e Tecnológico (CNPq) - Proc. ${ }^{\circ}$ 561655/2008-1 - Edital CNPq 006/2008 - Jovens Pesquisadores.

2 Texto completo disponível em: <http://www.rinace.net/reice/numeros/arts/ vol8num4/art4_htm.htm>. Acesso em: 15 out. 2011.

202 Educação \& Realidade, Porto Alegre, v. 38, n. 1, p. 179-204, jan./mar. 2013. Disponível em: <http://www.ufrgs.br/edu_realidade> 
3 Disponível em: <http://www.unesco.org/pt/confinteavi/background>. Acesso em: 15 out. 2011 .

4 FREIRE, Paulo. Terceira carta. Do assassinato de Galdino Jesus dos Santos - Índio pataxó. In: FREIRE, Paulo. Pedagogia da indignação. Cartas pedagógicas e outros escritos. São Paulo: UNESP, 2000. P. 31. Texto completo disponível em: <http:// portal.mda.gov.br/portal/saf/arquivos/view/ater/livros/Pedagogia_da_Indignação.pdf>. Acesso em: 24 jan. 2013.

\section{Referências}

ANDRIOLA, Wagner Bandeira. Utilização do Modelo CIPP na Avaliação de Programas Sociais: o caso do Projeto Educando para a Liberdade da SECAD/MEC. Revista Iberoamericana sobre Calidad, Eficacia y Cambio en Educación, Madrid, $n$. 8, v. 4, p. 65-82, 2010.

ANDRIOLA, Wagner Bandeira; HOLANDA, Zélia Maria; VITORINO, Grace Troccólli; MACHADO, Rosélia Castro C.; BARBOSA, Maria José; MAIA, Madeleine Gurgel. Projeto Educando para a Liberdade: a educação prisional em foco. In: Educação em Prisões da América Latina: direito, liberdade e cidadania. Brasília: Editora da UNESCO, 2009. P. 39-57.

ANDRIOLA, Wagner Bandeira; HOLANDA, Zélia Maria; VITORINO, Grace Troccólli; MACHADO, Rosélia Castro C; BARBOSA, Maria José; MAIA, Madeleine Gurgel. Proyecto Educando para la Libertad: la educación en establecimientos penitenciarios bajo el análisis. In: Educación en Prisiones Latinoamericanas. Brasília: UNESCO, 2008. P. 43-60.

ANDRIOLA, Wagner Bandeira. Evaluación: la vía para la calidad educativa. Ensaio. Avaliação e Políticas Públicas em Educação, Rio de Janeiro, n. 7, v. 25, p. 355-368, 1999.

BERK, Ronald; ROSSI, Peter Henry. Thinking about Program. Londres: SAGE, 1990.

BLANKENBERG, Francis. The Role of Planning, Monitoring and Evaluation. The Hague: Novib, 1995.

CAPUCHA, Luís; ALMEIDA, João Ferreira de; PEDROSO, Pedroso; SILVA, José Antonio Vieira da. Metodologias de avaliação: o estado da arte em Portugal. Sociologia: problemas e práticas, n. 22, p. 9-27, 1996.

CARVALHO, Sonia; WHITE, Howard. Performance Indicators to Monitor Poverty Reduction. Washington, DC: World Bank, 1995.

GIROUX, Henry. Os Professores como Intelectuais: rumo a uma pedagogia crítica da aprendizagem. Porto Alegre: Artes Médicas, 1997.

GOMES ANDRIOLA, Cristiany. Avaliação dos Docentes de Instituições de Ensino Superior (IES): o caso da Faculdade Cearense (FAC). Dissertação (Mestrado em Educação) - Programa de Pós-Graduação em Educação, Universidade Federal do Ceará (UFC), Fortaleza, 2011. No prelo.

GRACIANO, Mariângela; SCHILLING, Flávia. A Educação na Prisão: hesitações, limites e possibilidades. Estudos de Sociologia, São Paulo, v. 13, n. 25, p. 111-132, 2008.

JULIÃO, Elionaldo Fernandes. As Políticas de Educação para o Sistema Penitenciário: análise de uma experiência brasileira. In: ONOFRE, Elenice Maria Cammarosano (Org.). A Educação Escolar entre as Grades. São Carlos: EDUFSCAR, 2007. P. 29-50

Educação \& Realidade, Porto Alegre, v. 38, n. 1, p. 179-204, jan./mar. 2013.

Disponível em: <http://www.ufrgs.br/edu_realidade> 
JULIÃO, Elionaldo Fernandes. Educação e Trabalho como propostas políticas de execução penal. Revista de Educação de Jovens e Adultos: alfabetização e cidadania, Brasília, RAAAB/ UNESCO/ Governo Japonês, 2006.

ONOFRE, Elenice Maria Cammarosano (Org.). A Educação Escolar entre as Grades. São Carlos: EDUFSCAR, 2007.

PEDROZO, Euclides. Uma Avaliação ex-ante dos Impactos do Bolsa Família na Redução do Trabalho Infantil. In: XXXII ENCONTRO NACIONAL DE ECONOMIA, Anais... 2007.

ROSALES, Carlos. Criterios para una Evaluación Formativa. Madrid: Narcea, 1984.

SANTIAGO, Jayme; BRITTO, Tatiana Feitosa de. A Educação nas Prisões. Revista de Informação Legislativa, Brasília, ano 43, n. 171, p. 299-304, 2006.

SCRIVEN, Michael. Evaluation as a discipline. Studies in Educational Evaluation, v. 20, p. 147-166, 1994.

SERRADO JÚNIOR, Jerru Vieira. Políticas Públicas Educacionais no Âmbito do Sistema Penitenciário: aplicações e implicações no processo de (re)inserção social do apenado. 2009. 103 p. Dissertação (Mestrado em Educação) - Programa de Pós-Graduação em Educação, Universidade Estadual Paulista Júlio Mesquita Filho UNESP, Presidente Prudente, 2009.

SHADISH Jr., William; COOK, Thomas; LEVINTON, Laura. Foundations of Program Evaluation: theories of practice. Londres: SAGE, 1991.

SHON, Donald. Educando o Profissional Reflexivo: um novo design para o ensino e a aprendizagem. Porto Alegre: Artes Médicas Sul, 2000.

TEIXEIRA, José Carlos. O Papel da Educação como Programa de Reinserção Social para Jovens e Adultos Privados de Liberdade: perspectivas e avanços. In: EJA e Educação prisional, Boletim nº 06, p. 14-21. Brasília: SEED/MEC, 2007.

TELES, Jorge Luiz; DUARTE, Daniele. Avaliação como Processo: um olhar sobre o Projeto Educando para a Liberdade. In: UNESCO (Organização das Nações Unidas para a Educação, a Ciência e a Cultura). Educação em prisões na América Latina: direito, liberdade e cidadania. Brasília: UNESCO, OEI, AECID, 2009. P. 25-37.

THERRIEN, Jacques; SOBRINHO, José Henrique. Avaliação Institucional em Universidades: considerações metodológicas. Educação em Debate, Fortaleza, v. 6/7, n. $2 / 1$, p. 17-27, 1983/1984.

UNESCO (Organização das Nações Unidas para a Educação, a Ciência e a Cultura). Educação em Prisões na América Latina: direito, liberdade e cidadania. Brasília: UNESCO, OEI, AECID, 2009.

VILLELA PEREIRA, Marcos; DE LA FARE, Mónica. A Formação de Professores para Educação de Jovens e Adultos (EJA): as pesquisas na Argentina e no Brasil. Revista Brasileira de Estudos Pedagógicos, Brasília, v. 92, n. 230, p. 70-82, 2011.

Wagner Bandeira Andriola é professor Associado da Faculdade de Educação da Universidade Federal do Ceará (UFC) em Fortaleza/Ceará. Doutor em Filosofia e Ciências da Educação (Universidad Complutense de Madrid); Membro da Associação Brasileira de Avaliação Educacional (ABAVE); Coordenador do Curso de Especialização em EJA nas Prisões para Professores do Sistema Prisional do Ceará. Pesquisador do Conselho Nacional de Desenvolvimento Científico e Tecnológico (CNPq). País: Brasil - Fortaleza/ Ceará. E-mail: w_andriola@yahoo.com 